\title{
Delegitimizing Jews and Israel in Iran's International Holocaust Cartoon Contest
}

\author{
Rusi Jaspal, Ph.D. \\ De Montfort University
}

In 2006, the Iranian government-aligned newspaper Hamshahri sponsored The International Holocaust Cartoon Contest. The stated aim of the contest was to denounce "Western hypocrisy on freedom of speech," and to challenge "Western hegemony" in relation to Holocaust knowledge. This government-backed initiative was a clear attempt to export the Iranian regime's anti-Zionist agenda. Using qualitative thematic analysis and Social Representations Theory, this article provides an in-depth qualitative analysis of the cartoons submitted to the contest in order to identify emerging social representations of Jews and Israel. Three superordinate themes are outlined: (i) "Constructing the 'Evil Jew' and 'Brutal Israel' as a Universal Threat"; (ii) "Denying the Holocaust and Affirming Palestinian Suffering"; (iii) "Constructing International Subservience to 'Nazi-Zionist' Ideology". Although the organizers of the International Holocaust Cartoon Contest claimed that their aims were anti-Zionist, this article elucidates the overtly antiSemitic character of the contest and its cartoons. It is argued that the cartoons exhibit a distorted, one-sided version of the Israeli-Palestinian conflict and of Jewish history, and may therefore shape viewers' beliefs concerning Jews and Israel in fundamentally negative ways, with negative outcomes for intergroup relations and social harmony.

\section{CITING THIS ARTICLE}

Jaspal, R. (in press). Delegitimizing Jews and Israel in Iran's International Holocaust Cartoon Contest. Journal of Modern Jewish Studies

\section{CORRESPONDENCE}

Dr. Rusi Jaspal, Division of Psychology, School of Applied Social Sciences, Faculty of Health and Life Sciences, De Montfort University, Leicester LE1-9BH United Kingdom. Email: rusi.jaspal@gmail.com

\section{ACKNOWLEGEMENTS}

This author would like to thank Professor Glenda Abramson and two anonymous reviewers for their valuable and constructive feedback on an earlier version of this manuscript.

\footnotetext{
AUTHOR BIOGRAPHY

Dr Rusi Jaspal is Lecturer in Psychology at De Montfort University, Leicester, UK. He holds degrees from the University of Cambridge, University of Surrey and Royal Holloway, University of London. Dr Jaspal is currently writing a monograph entitled Antisemitism and Antizionism: Representation, Cognition and Everyday Talk which is to be published by Ashgate in 2014. Rusi Jaspal is co-editor (with Dame Glynis Breakwell) of Identity Process Theory: Identity, Social Action and Social Change (Cambridge University Press, 2013).
} 


\title{
Delegitimizing Jews and Israel in Iran's International Holocaust Cartoon Contest
}

\author{
Rusi Jaspal, Ph.D. \\ De Montfort University
}

Anti-Semitism can be defined as "prejudice and hostility towards Jews on the basis of their ethnocultural and/or religious group membership" (Jaspal, 2013a, p. 231). This age-old prejudice has manifested itself in various forms and guises over several centuries. In the Christian world, Jews were historically charged with the most heinous crime deemed possible - deicide, that is, the killing of God. In the Middle Ages, a blood libel against Jews (the accusation that Jews use the blood of children in order to prepare unleavened bread for Passover) surfaced and persisted, leading to widespread Judeophobia, pogroms, and the expulsion of the Jews from their host countries (Wistrich, 1999). Jews have been accused of world domination, such as the "control" of world banks and of US foreign policy (Herf, 2006). These are just some of the dominant themes that have historically characterized European anti-Semitism and gradually infiltrated themselves into social representations of Jews in the Middle East (Webman, 2010). The Islamic Republic of Iran makes no secret of its anti-Zionist stance which is frequently punctuated by blatant anti-Semitism (Shahvar, 2009).

The International Holocaust Cartoon Contest, which was organized by the governmentaligned Iranian newspaper Hamshahri, was a clear example of Iranian anti-Semitism presented superficially under the guise of anti-Zionism (Wistrich, 2004). There has been research into the social psychological aspects of anti-Semitism (e.g. Cohen et al., 2009; Jaspal, 2013a), and its historical, cultural and political underpinnings (e.g. Lindemann \& Levy, 2010; Litvak, 2006; Shahvar, 2009). Yet, despite the social and political importance of the 2006 cartoon contest and the general clout that visual representations can have in shaping public opinion and intergroup relations (Bounegro \& Forceville, 2011), there has been relatively little research into the visual aspects of anti-Semitism and no systematic analysis of the International Holocaust Cartoon Competition. Using qualitative thematic analysis and Social Representations Theory from social psychology, this article address this lacuna and provides an in-depth qualitative analysis of the cartoons submitted to the Iranian Holocaust Cartoon Competition in order to identify and examine emerging social representations of Jews and Israel.

\section{Anti-Semitism and Anti-Zionism}

In the Muslim Middle East, anti-Semitism is a growing problem with significant social and political ramifications. Anti-Semitism has gradually acquired social acceptability in some quarters, sometimes because it is positioned in the context of a historical religious conflict between Muslims and Jews (Litvak, 2008; Webman, 2010), but primarily because it is often manifested in the more socially acceptable guise of anti-Zionism (Chesler, 2003). The Islamic Republic of Iran presents itself as a leader in the international "campaign" against Zionism and openly calls for the dismantlement of the State of Israel. Since the 1979 Islamic Revolution, leading political figures, including the Supreme Leader and the president, have made blatantly anti-Semitic remarks, which are frequently grounded in (Shiite) Islamic theology. For instance, Ayatollah Khomeini, the first Supreme Leader, publicly compared Jews to apes and pigs and reiterated the Jews' alleged betrayal of the Prophet Muhammed (Shahvar, 2009). Given that Iran is home to the largest Jewish community in the Middle East outside of Israel, the Islamic Republic claims that it cannot possibly be anti-Semitic, while promulgating clearly discriminatory legislation limiting the rights of Iranian Jews (e.g. travel restrictions, see Klüsener, 2008).

Iran's overt policy of anti-Zionism has caused much controversy. Although the Iranian political leadership seeks to present itself as anti-Zionist rather than anti-Semitic, political figures 
and commentators often employ the categories "Jew," "Israeli" and "Zionist" interchangeably, which suggests an underlying conflation of these categories (Jaspal, 2013a). Its leaders express their desire to "wipe Israel off the map" and regard terrorist actions against the State of Israel and its people as legitimate acts of war (Menashri, 2006). For instance, Iran actively sponsors Hezbollah and Hamas, both of which are regarded by the US, Britain, Germany and France as terrorist organizations (Palmer-Harik, 2004). In addition to sponsoring terrorism, the Iranian regime employs more "symbolic" tactics against Israel - Holocaust denial is cynically employed to delegitimize the State of Israel and to contest its perceived raison d'être (Litvak \& Webman, 2009). Iran's former foreign minister Manoucher Motakki infamously declared that "if the official version of the Holocaust is thrown into doubt, then the identity and nature of Israel [also] will be thrown into doubt." ${ }^{2}$ Despite its intended use as an instrument of anti-Zionism, Holocaust denial is itself an act of anti-Semitism because, in addition to denying the worst tragedy in Jewish history, it implicitly represents Jews as deceiving the world for selfish gain (Litvak \& Webman, 2009).

\section{Anti-Semitic Cartoons in the Middle East}

Political cartoons have been a vehicle for promoting anti-Semitism and anti-Zionism. There has been some important research into cartoon depictions of Jews and Israel in the Arab World (Kotek, 2003, 2008; Smith, 2008; Stav, 1999). For instance, Kotek (2008) refers to prevalent beliefs about Jews constructed over centuries as "antisemyths," that is, myths and fears concerning the "evil" nature of Jews, which are represented in cartoon format. In the Arab/ Muslim world, anti-Semitic cartoons present a stereotypical image of Jews as a threat of various kinds. Israel is typically branded as an entity consisting of "fascists, warmongers, racists, childkillers and conspiring capitalists" (Wistrich, 2005, p. 40). These cartoons validate Judeophobic ideology and are intended to justify draconian measures against Jews and the Jewish State, as was observable in Nazi Germany (Herf, 2006). What is said to constitute "antiZionism" in fact draws upon overtly anti-Semitic motifs and is a blatant "combination of old clichés of hatred against Jews with new anti-Semitic arguments and anti-Israel feelings" (Taguieff, 2009, p. xi).

In his study of anti-Semitic cartoons in the international media, Smith (2012) notes that the Star of David constitutes a recurring motif as a symbol of both Jews and Israel, which is used in juxtaposition with negative imagery of Jews. Over half of the cartoons analyzed represent Jews as hostile, threatening agitators, which is consistent with the threat representation. The "bloodthirsty" category evoked the long-standing Jewish blood libel and constructed Jews as malevolent, sadistic and ruthless particularly in their treatment of Gentiles (Webman, 2010). In the "discrimination" category, Jews were visually ascribed negative physical traits stereotypically associated with Jews since the Middle Ages (Kotek, 2009). This ensured that Jews appear to be foreign and negatively distinctive, normalizing discrimination against them. The "demonic" concept represented Jews as unnatural and monstrous creatures, such as a vampire, a demon or the Devil Himself (Yadlin, 1999).

\section{The International Holocaust Cartoon Contest}

In September 2005, the Danish newspaper Jyllands-Posten published twelve cartoons which were deemed by many Muslims to defame the Prophet Muhammed and to ridicule Islam. This was followed by unrest in the Muslim world - there were attacks on Danish embassies in Damascus, Beirut, Benghazi and Tehran, and over a hundred people were killed in protests in

\footnotetext{
${ }^{1}$ http://web.archive.org/web/20070927213903/http://www.iribnews.ir/Full_en.asp?news_id=200247

2 http://www.haaretz.com/opinion/for-iran-the-holocaust-is-just-another-tragedy-if-it-everhappened.premium-1.502134
} 
Nigeria, Libya, Pakistan and Afghanistan (Fischer, 2009). It is noteworthy that Iran adopted a particularly hardline response to the Danish cartoons - President Ahmadinejad called for the cancelation of all existing contracts with Denmark and recalled the Iranian ambassador to Denmark, and the Supreme Leader Ayatollah Ali Khameini attributed the whole matter to a covert "Zionist conspiracy." As a further response to Danish cartoons controversy, in 2006, the Iranian newspaper Hamshahri, which is owned by the Tehran Municipality, sponsored The International Holocaust Cartoon Contest. The stated aim of the contest was to denounce "Western hypocrisy on freedom of speech" in reference to the West's response to the Danish cartoon controversy (Hussain, 2007). The organizers claimed that the Holocaust cartoon competition would challenge the boundaries of the Western notion of freedom of speech by problematizing the veracity of the Holocaust. However, it was claimed that the contest was not intended to offend or ridicule Jews, but to reiterate opposition to Zionism and the State of Israel. Yet, the contest clearly exhibited the extent of anti-Semitism in the Iranian regime and its willingness to use anti-Semitism for political ends (Küntzel, 2010). Indeed, Massoud Shojaie, the director of Iran's Caricature House, reportedly told the Associated Press that "actually we will continue until the destruction of Israel." 3 It is likely that Holocaust denial was selected as the theme of the cartoon contest due to its ability to shock sensibilities and to provoke outrage in the West, which would in turn "evidence" the Iranian regime's claim that the Western world silences "scientific debate" concerning the Holocaust and impedes freedom of speech (Küntzel, 2012).

Cartoonists from 32 countries contributed to the contest, although most submissions came from Iran itself (see figure 1).

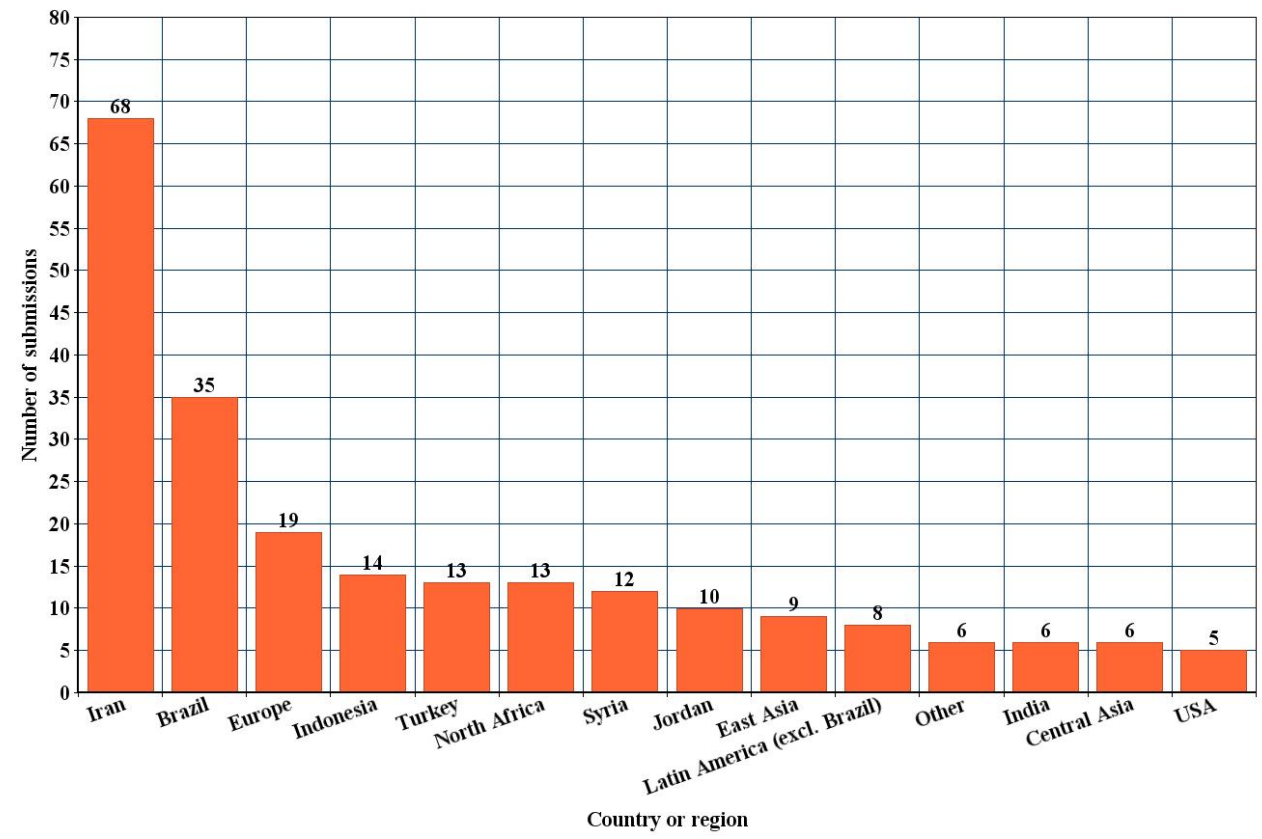

Figure 1: Contributors to the 2006 International Holocaust Cartoon Competition

The organizers decided that the "best" fifteen cartoons would be awarded prizes ranging from three gold coins to $\$ 12,000$. The criteria used by the organizers in judging the quality of the cartoons have not been made publicly available, but an overview of the winning cartoons is provided in table 1.

${ }^{3}$ http://seattletimes.com/html/nationworld/2003337932_webcartoons01.html 


\begin{tabular}{|c|c|c|c|c|}
\hline & Name of artist & Country & Content & Prize \\
\hline 1 & Abdellah Derkaoui & Morocco & Auschwitz re-created by Zionist bulldozer & $\$ 12,000$ \\
\hline 2 & Carlos Latuff & Brazil & Bereft palestinian in Auschwitz uniform & $\$ 8000$ \\
\hline 2 & Chard & France & "Myth" of gas chambers toppled & declined \\
\hline 3 & Shahram Rezaei & Iran & $\begin{array}{l}\text { Mass burial of paper people by Nazi } \\
\text { soldiers }\end{array}$ & $£ 5000$ \\
\hline 4 & $\begin{array}{l}\text { Mohamad Reza } \\
\text { Dostmohamadi }\end{array}$ & Iran & $\begin{array}{l}\text { Crowd around a Jew crying crocodile } \\
\text { tears due to Holocaust }\end{array}$ & $\begin{array}{l}3 \text { gold } \\
\text { coins }\end{array}$ \\
\hline 5 & Maziyar Bizhani & Iran & $\begin{array}{l}\text { Holocaust museum in the shape of } \\
\text { swastika }\end{array}$ & " \\
\hline 6 & Mahmoud Nazari & Iran & $\begin{array}{l}\text { Jews' noses grow due to Holocaust lies } \\
\text { and destroy a Palestinian home }\end{array}$ & " \\
\hline 7 & Jaber Asadi & Iran & $\begin{array}{l}\text { Giant Zionist soldier uses Holocaust grave } \\
\text { as a shield }\end{array}$ & " \\
\hline 8 & Vahid Khodayar & Iran & $\begin{array}{l}\text { Disorganized group of Jews laughing and } \\
\text { celebrating }\end{array}$ & " \\
\hline 9 & Eloar Guazzelli & Brazil & Israeli tank descents a steep hill & $"$ \\
\hline 10 & Omar Adnan & Jordan & $\begin{array}{l}\text { A yellow chick declares that it "wants a } \\
\text { country like Israel" }\end{array}$ & " \\
\hline 11 & Naji Benaji & Morocco & $\begin{array}{l}\text { Palestinian bottle is full of skulls while } \\
\text { Holocaust bottle contains very few skulls }\end{array}$ & " \\
\hline 12 & Alessandro Gatto & Italy & $\begin{array}{l}\text { A bereft Palestinian resides in the empty } \\
\text { uniform of an Auschwitz prisoner }\end{array}$ & " \\
\hline 13 & Raed Khalil & Syria & $\begin{array}{l}\text { Two hands in handcuffs constituting the } \\
\text { 'o's of the word "Holocaust" }\end{array}$ & " \\
\hline 14 & Naser Al Jafari & Jordan & $\begin{array}{l}\text { Palestine located in a swastika-shaped } \\
\text { trench in drought-afflicted land }\end{array}$ & " \\
\hline 15 & Casso & Brazil & $\begin{array}{l}\text { UN wreath placed on grave of 'Palestinian } \\
\text { Holocaust' victims }\end{array}$ & " \\
\hline
\end{tabular}

Table 1: Overview of the prize-winning cartoons

Following the cartoon competition, the Iran Cartoon Organization and Hamshahri organized an exhibition at the Palestine Museum of Contemporary Art in Tehran, which gave further exposure to the cartoons. In organizing the cartoon contest, Hamshahri did not act independently but rather with the endorsement of the Iranian political leadership. Both the Iranian Supreme Leader Ali Khamenei and President Mahmoud Ahmadinejad expressed support for the contest and referred to the importance of contesting "Western hegemony" concerning the Holocaust. Indeed, in December of the same year, President Ahmadinejad hosted the International Conference to Review the Global Vision of the Holocaust in Tehran, which brought together Holocaust deniers from some 60 countries. In short, the Iranian cartoon contest can plausibly be regarded as a journalistic extension of Iranian state ideology in which anti-Zionism and anti-Semitism play an important role (Jaspal, 2013a).

\section{Social Representations Theory}

Using the International Holocaust Cartoon Contest as a case study, this study examines emerging social representations of Jews and Israel. Social Representations Theory provides a framework for understanding everyday social thinking, communication and behavior (Moscovici, 1963, 1988). According to the theory, a social representation constitutes a structure of values, descriptors and practices regarding a given social object, as well as "the elaborating of a social object by the community for the purpose of behaving and communicating" (Moscovici, 1963, p. 251). Social representations are context-dependent and create what one might call a shared social reality in which discussion of Jews and Israel can take place.

Jaspal (2013b, in press) has argued that delegitimizing social representations of Israel in 
the mainstream Iranian media, for instance, provide the readership with a negative social "reality" in relation to Jews and Israel, facilitating anti-Semitism. Political cartoons too have the power to shape and contribute to emerging social representations. Although cartoons typically satirize actual events, they "draw from the available stock of public knowledge and reproduce a common sense view of the world" (Greenberg, 2002, p. 184). They merge visual representations with cultural associations in order to generate meaning among viewers. As Moloney, Holtz and Wagner (2013, p. 287-88) argue, "the visual aspect of the cartoon reproduces social representations, the interpretability of which is premised on an implicit interdependence between the image and the viewer."

In his analysis of how representations are formed, Moscovici (1988) outlines two processes that underlie the formation of social representations, namely anchoring and objectification. Anchoring refers to the process of making something unfamiliar understandable by linking it to something familiar. Objectification is the process whereby unfamiliar and abstract objects are transformed into concrete and "objective" common-sense realities. Using the International Holocaust Cartoon Contest as a case study, this article examines how the processes of anchoring and objectification function visually in order to construct particular social representations of Jews and Israel.

\section{METHOD}

All 227 cartoon submissions were available to download on the Irancartoon Web Gallery website. ${ }^{1}$ The 227 cartoons were analyzed using qualitative thematic analysis, which has been described as "a method for identifying, analyzing and reporting patterns (themes) within data" (Braun \& Clarke, 2006, p.78). These patterns of meaning are represented as "themes." The constructionist variant of the technique can be employed to "unpick or unravel the surface of 'reality"' (Braun \& Clarke, 2006, p.81). While thematic analysis has typically been employed in the analysis of textual datasets, this study applies the method to the analysis of visual representations in order to identify social representations of Jews and Israel embodied in cartoons concerning the Holocaust. Indeed, Lindner (2006, p.108) has observed that "images can be analyzed as text; that is, they can be broken up into elements and linked to meanings, in the same way that text can be reduced to words that have denotative and connotative associations." Accordingly, the approach can help to identify messages, symbols and meanings, including emotive meanings, conveyed by the cartoons submitted to the contest. We refer to this approach as visual thematic analysis (see also Nerlich \& Jaspal, in press).

Thematic analysis was deemed to be advantageous because it can allow the analyst to integrate the micro and macro levels of analysis. Indeed, our analysis "goes beyond the semantic content of the data [that is, the micro level], and starts to identify [...] the underlying ideas, assumptions and conceptualizations - and ideologies - [that is, the macro level] that are theorized as shaping or informing the semantic content of the data" (Braun \& Clarke, 2006, p. 84). For instance, while at the micro level a cartoon may depict a prisoner concentration camp, at a macro level this resonates with imagery of the Holocaust and perhaps genocide, more generally. Our aim in this article is to provide a rich thematic description of a relatively small corpus of cartoons, which can elucidate emerging social representations of Jews and Israel. Given the dearth of research into cartoon representations of Jews and Israel, we adopt an inductive approach whereby the themes are closely linked to the data themselves, and thus data-driven, rather than interpreted through the lens of any pre-existing theory (Patton, 1990).

There were three cycles of data ordering and thematic coding. First, all 227 cartoons were listed on a spreadsheet in Excel, in which four columns were created: (i) the name of the artist; (ii) their country of origin; (iii) a detailed description of the cartoon (preliminary coding); and (iv) a theoretically informed interpretation of the image (secondary coding). Second, the author roughly coded the cartoons and discussed these preliminary analyses with two research assistants, 
focusing especially on the thematic coding categories used (Braun \& Clarke, 2006). Collaborative coding in this manner is one means of safeguarding quality in qualitative (visual) research (Elliot, Fischer \& Rennie, 1999). Finally, the author undertook theoretically-informed coding which was informed by the discussions with the research assistants.

The analyst focused upon representations of Jews and Israel in particular, that is, upon (i) the constructed "essence" of Jews and Israel; (ii) their relationships with others (e.g. Palestinians); (iii) historical events associated with Jews and Israel (primarily, the Holocaust). The analytical codes captured the essential qualities of the cartoons, such as inter alia the components of each cartoon, its general tone, its potential emotive force, the presence of other groups, and emerging patterns within the data. Subsequently, these codes were collated in order to create overarching themes characterizing the corpus of cartoons. Finally, superordinate themes representing the themes derived from the analysis were developed and ordered into a logical and coherent narrative structure. Relevant constructs from Social Representations Theory (such as anchoring and objectification) were drawn upon as a means of theoretically enriching the analysis. All source information regarding the cartoons discussed in the paper is included in the endnotes.

\section{ANALYSIS}

This section outlines the following three superordinate themes which emerged from the analysis:

(i) "Constructing the 'Evil Jew' and 'Brutal Israel' as a Universal Threat"; (ii) "Denying the Holocaust and Affirming Palestinian Suffering"; (iii) "Constructing International Subservience to 'Nazi-Zionist' Ideology".

\section{Constructing the "Evil Jew" and "Brutal Israel" as a Universal Threat}

Cartoonists construct and conflate images of the "Evil Jew" and "Brutal Israel" in order to construct the social representation that this hybrid "entity" poses a universal threat, that is, to Palestinians, Muslims and the world, more generally.

The cartoons consistently construct Jews in particular as immoral evil beings whose intentions are inherently malevolent. In a cartoon by Abdolhossein Amirizadeh from Iran, ${ }^{2}$ the Devil is depicted against a fiery hellish landscape. The figure possesses the physical traits typically attributed to the Devil, such as long and sharp claws, horns, sharp and jagged teeth and pointy ears, but it is also attributed physical traits historically and stereotypically associated with the Jews in anti-Semitic images, e.g. a long face and a hooked nose (Kotek, 2009; Smith, 2012). The Devil possesses a pitchfork with a Star of David and is depicted as reading a large book entitled "Holocaust" which also displays the Star of David, implying that the Devil is a Jew. Similarly, another cartoon ${ }^{3}$ by Majid Salehi from Iran represents a devilish figure brandishing a pitchfork with a menorah, also emphasizing the Jewish character of the devilish figure. In two cartoons by Sadic Pala from India, Jews are depicted as parasitical vampire bats (see image 1), which constituted a prevalent long-standing motif in medieval European anti-Semitism (Kotek, 2009). In one image, ${ }^{4}$ a Jew with sidelocks and a black hat is depicted as a vampire bat with fangs, hanging upside down alongside a real vampire bat. This serves to construct a sense of "natural" solidarity and camaraderie between the vampire Jew and the vampire bat. The vampire Jew foregrounds and presides over Jerusalem - itself represented by a mosque in the background. In the other image, ${ }^{5}$ a Jew with sidelocks and a black hat wearing the Star of David is depicted as a vampire with long sharp fangs feeding parasitically on "Palestinian blood." In short, these cartoons anchor Jews to stereotypically evil and parasitic beings. 


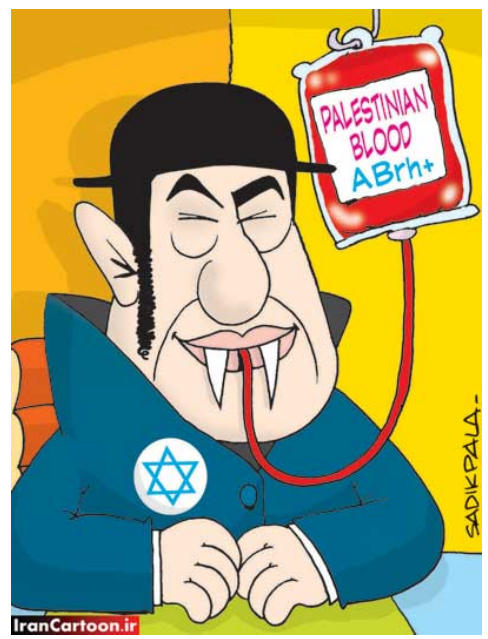

Image 1: (C) Irancartoon.ir

In addition to embodying evil, Jews are represented as opposing righteousness (Herf, 2006). Alaa Rostam from Syria ${ }^{6}$ depicts an obese menacing-looking Jew with sidelocks wearing a Hasidic black hat on his head and a large weapon on his back. He is represented as drawing a target on the back of an apparently benevolent individual recounting the "truth" of the Holocaust, namely that it never occurred. The constructed aim of the "Evil Jew" is the silencing of this "truth." In another cartoon, ${ }^{7}$ Sam Keshmiri from Iran represents a large beast-like figure with sidelocks and a hooked nose next to an angelic child who bleeds, suggesting that the Jewish beast has attacked the child and therefore constitutes the antithesis of the angel, namely evil itself. Similarly, in a caricature by Majid Salehi from Iran, ${ }^{8}$ a stereotypically demonic-looking Jew (also with long sidelocks and a hooked nose) who is carrying a briefcase displaying the Israeli flag carries an incapacitated angel tied tightly to his back. In his cartoon, ${ }^{9}$ Behnam Bahrami represents an evil devilish figure with red eyes, fangs and pointy ears who is also wearing a Jewish black hat displaying the Star of David. His elongated nose, implicitly attributed to his "lies" about the Holocaust, brutally penetrates a bloodied white dove that was carrying an olive branch. In these cartoons, peace and benevolence (symbolized by the dove and angel, respectively) are brutalized by the hybrid symbol of the "Evil Jew" who is constructed as a threat to peace. These cartoons serve to anchor Judaism to war-mongering.

Cartoonists make use of existing anti-Semitic social representations (e.g. that Jews are evil) in order to derogate Israelis (Wistrich, 2005). In a cartoon by Augusto Frank Bier from Brazil, ${ }^{10}$ an Israeli soldier on a tank displaying the Star of David is depicted as conversing with the Grim Reaper, the personification of death, who angrily rebukes the Israeli soldier for interfering in "his business," namely death and destruction. Like the "Evil Jew" who causes death and destruction, the State of Israel is depicted as the gasoline which deliberately and callously burns innocent and helpless Lebanese children. This serves to objectify the victim of Jewish-Zionist aggression through the process of personification. Death and destruction are represented as the principal aim of the State of Israel in a cartoon by Carlos Latuff, given that the gasoline bottles displays the flag of Israel and is intended to symbolize the Jewish state. ${ }^{11}$ Similarly, in another cartoon by the same artist, ${ }^{12}$ former prime minister Ehud Olmert (a personification of the State of Israel) is depicted as a gigantic evil figure towering domineeringly over both Gaza and Lebanon and unleashing devastating bombs single-handedly, causing death and destruction in both territories. In this cartoon, innocent Palestinian and Lebanese civilians are represented as running helplessly for cover from the bombs.

Several cartoonists depict the Palestinian family as the principal and intended victim of Israel, symbolized by the Israeli Defense Forces. For instance, in a cartoon by an anonymous artist from Brazil, ${ }^{13}$ a visibly terrified Palestinian family lies embedded within the ground 
surrounded by Israeli bombs all of which display the Star of David. Their house in the background lies in complete destruction and smoke engulfs the landscape. Furthermore, Miroslaw Hajnos from Poland ${ }^{14}$ represents an Israeli soldier as sadistically playing on a seesaw consisting of a plank balanced on a large missile with a terrified Palestinian family. The central theme of the cartoon concerns the sadism of Israel and the enjoyment that its soldiers derive from terrorizing the Palestinians. Consistent with this theme, J Bosco from Brazil produces a cartoon $^{15}$ in which an Israeli tank displaying the Star of David as its flag traverses the Palestinian landscape (displaying a sign marked "Palestine") and leaves a long trail of human skulls behind it, suggesting the brutality of the Israeli army and the destruction it leaves behind.

The "Evil Jew" and "Brutal Israel" are depicted as being collectively destructive to Palestine in particular. David Baldinger's cartoon ${ }^{16}$ depicts the Star of David (a symbol of both Judaism and Israel) as a shuriken (or throwing star) used to slash and maim Palestine, as suggested by its embedment within a dilapidated wall displaying the Palestinian national flag (symbolizing Palestine itself). The wall bleeds and smoke emerges from behind it, suggesting widespread death and destruction in Palestine. Moreover, the consequential suffering of the Palestinians is emphasized (Litvak \& Webman, 2009). For instance, in a caricature by Ebrahim Azad from Iran, ${ }^{17}$ Palestinians are depicted as being led systematically from a concentration camp (referred to as "Palestine") into an incinerator (caricatured as a Jewish head wearing a black hat with a Star of David). The incinerator excretes human skulls at the other end, which implicitly applies the social representation of the Holocaust to the Palestinian context. In short, the Jewish-Israeli is said to perpetrate genocide against the Palestinians. Judaism and Zionism are objectified in terms of violence and deadly phenomena, which provides these religious and political ideologies with a negative psychologically tangible essence.

The cartoons construct Israeli brutality as deliberate and calculated (Wistrich, 2005). In a cartoon by Raed Khalil from Syria, ${ }^{18}$ grinning, evil-looking Israeli soldiers pose for a photograph next to a dying Palestinian man lying in a pool of blood. The smoke emerging from their weapons suggests that they are responsible for this act of brutality and their grins suggest the calculation and joy with which the act was carried out. The soldiers stand defiantly before the Al-Aqsa Mosque, one of the holiest sites in Islam.

In addition to cartoons depicting the Jew-Zionist as an aggressor against the Palestinians, in particular, often symbolized by a sign "Palestine" or the Palestinian national flag, several images represent the Jew-Zionist as a threat to, or brutalizer of, Muslims more generally. In a cartoon by Djoko Susilo from Indonesia, ${ }^{19}$ the Star of David is again depicted as a throwing star which penetrates a crescent (a symbol of Islam) which bleeds. Similarly, images of the victimhood and suffering of Islam and Muslims (implicitly at the hands of the Jew-Zionist) are reiterated in another cartoon ${ }^{20}$ of a human eye displaying the crescent (a symbol of Islam) in place of the pupil shedding a single tear. Contributing to the image of an Israeli threat, a cartoon by Raed Khalil from Syria ${ }^{21}$ depicts a soldier (wearing a Star of David on his uniform) emerging from a hole and joyfully brandishing his weapon in the vicinity of the Al-Aqsa Mosque, which is barely visible behind explosions, debris and smoke. This serves to attribute the destruction of one of the holiest sites in Islam to the Israeli army. Furthermore, there is an implicit anchoring of the Israeli-Palestinian conflict to historical religious conflict between Jews and Muslims - this has performed an important mobilizing function in Arab/Iranian anti-Zionist discourse (Jaspal, 2013a, 2013b).

While Israel is habitually represented as brutalizing the Palestinians and threatening Islam, some cartoons depict Israel as posing a threat to the world as a whole (Herf, 2006). For instance, one cartoon 22 depicts the word "Israel" and replaces the final "l" with a large boot trampling on the globe (see image 2). The globe is represented as falling victim to Israel, an allegedly threatening and brutal entity. Similarly, this threat is reiterated in an image by Nedal Ali Deep from Syria $^{23}$ which represents Israel/Jews as an aggressive and malevolent dog with a 
demonic face barking viciously at a personification of the world, which attempts to appease the vicious dog with a piece of meat (displaying "Palestine"). In short, the ultimate target of the vicious dog, namely Israel/ Jews is the whole world, rather than Palestine specifically - Palestine is merely a means of appeasing the Jew-Zionist who allegedly seeks to usurp the world. The construction of the world as the ultimate target serves to crystallize and accentuate the social representation of the Jew-Zionist as posing a threat.

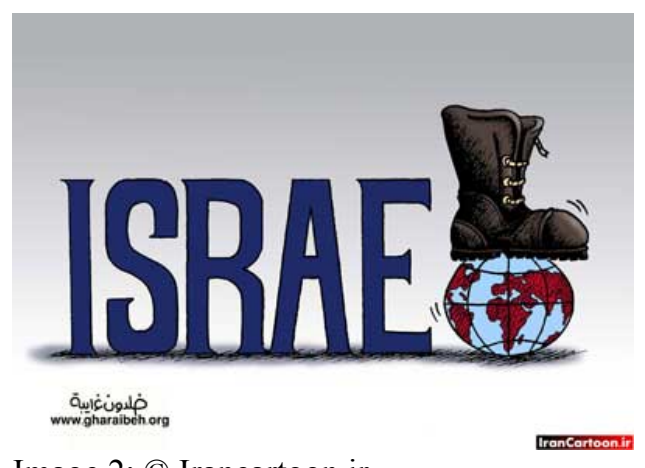

Image 2: (C) Irancartoon.ir

\section{Denying the Holocaust and Affirming Palestinian Suffering}

Cartoonists contest what are regarded in the Islamic Republic as "hegemonic" narratives regarding the Holocaust by constructing the Holocaust as a Jewish "myth" concocted by Jews and Zionist; as a facilitator of brutality against Palestinians and, occasionally, as an event that may have taken place but that caused more harm to the Palestinian than it did to the Jews.

Several images represent the Holocaust as a Jewish invention and Jews as malevolently deceiving the world with this "myth" for strategic gain (Litvak \& Webman, 2009). For instance, Homayoun Abdolrahimi from Iran ${ }^{24}$ depicts a Jew (wearing a Star of David on his arm) making a public announcement concerning the Holocaust. The Jew is depicted as undergoing the "Pinocchio Effect" (his nose has grown exceptionally long), which suggests that he deceives his audience about the Holocaust. Indeed, the length of his nose is intended to reflect the magnitude of the "lie." Indeed, Holocaust deniers typically refer to the Holocaust as one of the "greatest" lies ever perpetrated (Lipstadt, 1994). Similarly, a cartoon by Amir Baghestani from Iran ${ }^{25}$ depicts three Jews - one of them creating an Israeli flag by hand; another controlling the world, indicated by the position of the globe at his feet; and the third Jew with a Pinocchio-like nose holding a placard depicting the word "Holocaust." Crucially, the Jew who controls the world "assists" his collaborator who "lies" about the Holocaust by attempting to cut off his long nose with an axe. This cartoon constructs the Jews as deceiving the world but also as possessing a willingness to assist one another in perpetuating the "lie." This echoes social representations of Jewish world domination embodied in anti-Semitic conspiracy theories (Lindemann \& Levy, 2012). More generally, there is an anchoring of Judaism and Zionism to dishonesty and fraudulent behavior, providing a negative lens for regarding these ideologies.

There is a constructed interplay between Jews and Zionists in concocting the "Holocaust myth." A cartoon by Rahim Taghipour Sedgh Razmi from Iran ${ }^{26}$ attributes the "Holocaust myth" to the State of Israel by displaying the word "Holocaust" followed by "Made in Israel." The cartoon constructs this as a Zionist fabrication (Litvak \& Webman, 2009). Conversely, in a cartoon by Tallil Abdellatif from Morocco, ${ }^{27}$ a smiling Jew (wearing a black hat with a Star of David and sidelocks) draws onto his white shirt the vertical blue lines of the Auschwitz concentration camp prisoner uniform, while the world stands behind and observes him gagged (see image 3). Thus, the Holocaust is represented as a Jewish scam and the world as a helpless bystander (Lipstadt, 1994). Similarly, a cartoon by Hossein Taheri from $\operatorname{Iran}^{28}$ represents the "Evil Jew" (depicted as an ugly and hairy beast-like figure wearing a Jewish skullcap) as 
concocting a toxic potion labeled as "Holocaust" by mixing caustic (a chemical which is able to burn organic tissue) and another chemical labeled as "hollow" (referring to the alleged hollowness of the "Holocaust myth"). On the one hand, this constructs the Holocaust as a makebelieve Jewish creation and, on the other, as a highly toxic one which poses a hazard. The metaphorical objectification of the Holocaust in terms of a toxic substance serves to delegitimize well-established knowledge concerning the Holocaust and to re-construct it as a damaging hoax.

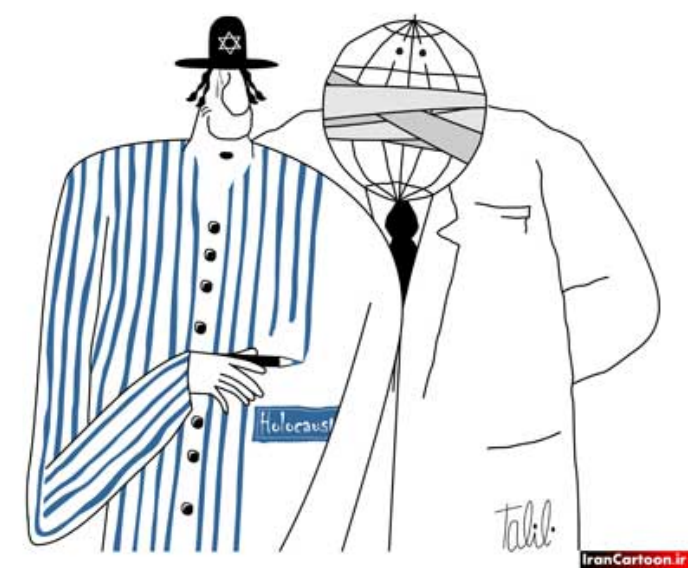

Image 3: (C) Irancartoon.ir

It is implied in many cartoons that the toxicity of the "Holocaust myth" consists primarily of its facilitation of brutality against the Palestinian people in particular. Maziyar Bizhani from Iran $^{29}$ depicts a Jew flying in a hot air balloon with the word "Holocaust" printed across it. From the sky, the Jew aims his rifle at a young Palestinian boy holding a slingshot, which constructs disparity between the alleged power of the Jews (who disseminate the "Holocaust myth") versus that of the Palestinians. Similarly, in another cartoon by Jihad Awrtani from Jordan, ${ }^{30}$ a terrifiedlooking Palestinian man is being beheaded by a large sword with Holocaust written across it, which represents the Holocaust as a (Jewish-Zionist) weapon used against innocent Palestinians. In another contribution, ${ }^{31}$ the same cartoonist represents the " $t$ " in "Holocaust" as the crucifix of a Palestinian man wearing a keffiyeh. Each nail used to crucify the Palestinian displays the word "Holocaust." In a cartoon by Sadic Pala from India, ${ }^{32}$ a grinning Israeli soldier stands on two book volumes entitled "Holocaust 1" and "Holocaust 2" in order to reach over a wall and fire his rifle at Palestinian civilians. The Israeli soldier is depicted as sadistically deriving enjoyment from killing his Palestinian civilian victims. Similarly, in various cartoons by Jaber Asadi from Iran, Israeli soldiers use the Holocaust to defend themselves physically while perpetrating acts of brutality against others. One cartoon ${ }^{33}$ depicts a giant Israeli soldier holding a tank in one hand and a Holocaust gravestone as a shield in the other. This suggests that the giant soldier who is indeed potent enough to hold a tank in one hand callously makes use of the "Holocaust myth" for self-defense. In the other cartoon, ${ }^{34}$ an Israeli soldier clutches onto a Holocaust gravestone in order to avoid falling from a cliff, which constructs the Holocaust as a lifeline for Israel (and its army). These cartoons, collectively, suggest that the Holocaust is maliciously utilized by the Jew-Zionist in order to terrorize the Palestinians and others. The Holocaust is anchored to functionality, rather than to factual history, which depicts it as a "useful" narrative, rather than a truthful one.

A number of cartoons construct the Nazi Holocaust as a myth and the "Palestinian Holocaust" as the true one. For instance, Tommy Thomdean ${ }^{35}$ from Indonesia depicts the Grim Reaper as reading a book entitled "Holocaust History" which displays the Palestinian flag, rather than a Jewish symbol, suggesting that the "true" Holocaust is the Palestinian one. Crucially, the Palestinian "Holocaust" is implied to be so chilling and devastating that even the Grim Reaper 
shudders in fear. In a cartoon by Gatto Alessandro from Italy ${ }^{36}$ an empty Auschwitz prisoner uniform is depicted as the wall and window of a prisoner cell in which a somber-looking Palestinian is imprisoned. Like Taheri's aforementioned cartoon, the empty uniform symbolizes the "hollowness" of the Holocaust narrative. Similarly, a cartoon by Carlos Latuff from Brazil ${ }^{37}$ depicts a Palestinian man wearing a keffiyeh and an Auschwitz prisoner uniform with a red crescent (symbolizing Islam) rather than a Star of David. The prisoner is located within a concentration camp. Crucially, the Palestinian Holocaust is represented as being so severe that it surpasses any act that the Nazis "may" have committed against the Jews. For instance, Abdellah Derkaoui from Morocco $^{38}$ represents an Israeli bulldozer as constructing a wall in front of the Al Aqsa Mosque. The wall displays the Auschwitz concentration camp which obscures the Al Aqsa Mosque, suggesting that Israel has itself rendered Palestine a concentration camp much like Auschwitz.

However, some cartoonists appear to acknowledge the veracity of Holocaust knowledge but nonetheless construct the Palestinians as suffering the "ongoing" consequences, which allegedly surpass Jewish suffering in the Nazi Holocaust. For instance, in a cartoon by Shiva Sahamifard from Iran, ${ }^{39}$ a Jew has been stabbed with a blade displaying the Nazi swastika but the blade has passed through the Jew's body and threatens to harm a Palestinian family at the other end. This represents the Palestinians as the innocent victims of the Nazi Holocaust. Similarly, Sidnei Marques from Brazil ${ }^{40}$ depicts Hitler as inserting his pistol into the ear of a Jew - the pistol passes through the Jew's skull and poses a danger to an innocent Palestinian man. Galym Boranbayev from Kazakhstan ${ }^{41}$ depicts a deceased Jew who has been hanged with a noose displaying the word "Holocaust." However, two Palestinians have in turn been hanged with the sidelocks of the deceased Jew. Similarly, a cartoon by Soheil Setayesh from Iran $^{42}$ depicts two books about the Holocaust, one of which has been authored by Hitler (referring to the Nazi Holocaust) and the other by Ariel Sharon, the former prime minister of Israel. This suggests that, despite the Holocaust perpetrated against the Jews, Israel is guilty of perpetrating a "Holocaust" of its own against the Palestinian people. Collectively, these cartoons do acknowledge the Nazi Holocaust but they function to either attenuate its significance vis-à-vis Palestinian suffering and to construct the Palestinians as innocent ongoing victims of the Holocaust, for which Israel is held responsible (Litvak \& Webman, 2009). Incidentally, these cartoons anchor Palestinian suffering to the Nazi Holocaust, in order to provide a lens for considering the extent of Palestinian suffering.

\section{Constructing International Subservience to "Nazi-Zionist" Ideology}

There is a consistent depiction of Jews and Israelis as Nazis, and of Zionism as overlapping with Nazi ideology (Litvak \& Webman, 2009). Cartoonists represent the world as being subservient to the "Nazi-Zionist" ideology due partly to an alleged international conspiracy (involving the US and UK, primarily) and to the constructed power of the "Holocaust myth."

Several cartoonists depict Zionism and Nazism as two sides of the same coin. Choukri Bellahadi from Algeria ${ }^{43}$ depicts the flag of Israel, which has been partially peeled off to reveal an underlying Nazi flag (the swastika). This constructs an underlying Nazi ideology as being superficially "camouflaged" by an Israeli flag, thereby representing synergy between the two ideologies. Similarly, a more abstract image by Mohammad Aman from Bahrain ${ }^{44}$ represents a falling Star of David which gradually becomes a swastika symbol, suggesting a natural metamorphosis of Zionism into Nazism. Some cartoonists construct the unifying thread between Zionism and Nazism as brutality by depicting lethal instruments. For instance, Alireza Nosrati from $\operatorname{Iran}^{45}$ depicts a blood-stained axe which displays the symbols of both Nazism (the swastika) and of Zionism (the Star of David). Crucially, the axe is double beveled - the swastika is displayed on the smaller blade which has less blood on it than the larger blade displaying the 
Star of David. This suggests that, despite synergy between the ideologies, it is the Zionists who have more blood on their hands than the Nazis.

Cartoonists depict symbolic figures of Nazism and Zionism, particularly Hitler and Sharon, respectively, in order to conflate the two ideological movements. For instance, Maziyar Bizhani from $\operatorname{Iran}^{46}$ depicts Hitler typically dressed in his Nazi uniform, but his toothbrush moustache is represented as a Star of David, suggesting a form of synergy between Hitler and Zionism. Conversely, in cartoons by Mohammad Aman from Bahrain ${ }^{47}$ and Leo Garesia from the USA, ${ }^{48}$ former Israeli prime minister Ariel Sharon is represented as a Nazi officer. In Garesi's cartoon, he is depicted as wearing a Star of David on one arm and the Nazi swastika on the other, while displaying the "SS" symbol of the Nazi Schutzstaffel on his collars. Similarly, Aman's cartoon represents Sharon as a ghost-like figure wearing a Jewish skullcap and a Nazi uniform (see image 4). His uniform displays the SS Totenkopf ("death's head"), which was used by the SS between 1934-45, as well as the Nazi party eagle symbol which, instead of the swastika, displays the Star of David. Wearing a Nazi uniform which also incorporates Zionist symbols, Sharon stands before the flag of Israel. In both cartoons, there is a constructed synergy and hybridity between Nazism and Zionism (Smith, 2012), which is represented as being embodied by Ariel Sharon, himself a personification of Israel. Yet, there is also a more general conflation of Jews and Nazis, as exemplified by a cartoon by Yasin Alkhalil from Syria. ${ }^{49} \mathrm{He}$ depicts a Jew (stereotypically represented as having a hooked nose and evil grin) holding a large knife and surrounded by a long trail of human skulls leading from the Al Aqsa Mosque. The Jew's reflection in the mirror is Hitler, wearing his military uniform with Nazi swastikas. The wellknown atrocities of Hitler and the constructed atrocities of the grinning, knife-wielding Jew in the cartoon are intended to represent Zionism as another form of Nazism. These cartoons anchor Zionism to the Nazi ideology, providing a lens for regarding and evaluating the ideology underlying the State of Israel.

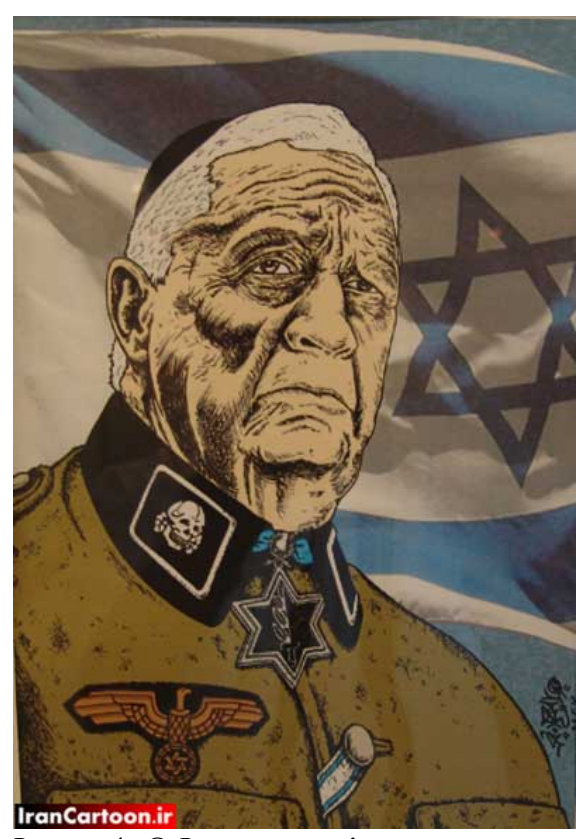

Image 4: (C) Irancartoon.ir

In addition to conflating Nazism and Zionism, some cartoons construct a collaboration between the hybrid Nazi-Zionist alliance, the US and other Western powers (Litvak \& Webman, 2009). For example, Jitet Koestana from Indonesia ${ }^{50}$ represents a figure with a toothbrush moustache (Hitler), a long beard and sidelocks (the Jew-Zionist) and an Uncle Sam hat (the US). Similarly, a cartoon by Gavimo from Brazil ${ }^{51}$ depicts the US flag with 50 stars in the form of the Star of 
David, which conflates Israel and the US. Reiterating the close relationship between Israel and the US, a cartoon by Esmail Babai ${ }^{52}$ depicts an Orthodox Jewish infant (wearing a black hat with sidelocks) asleep in a cot that displays the sign "Made in the US." Moreover, the Jew is covered with a blanket in the form of the UK Union Flag. Crucially, the cot has been placed at the doorstep of Palestine, which implies that the UK and US have played a fundamental role in creating and supporting Zionism/ the State of Israel. Cartoonists represent the collaboration between the US, UK and Israel as being a malevolent one, which has resulted in Palestinian suffering. Naji Benji ${ }^{53}$ depicts two smiling British and American men restraining a tearful Palestinian as a grinning Jew with sidelocks brands the man with a red hot iron in the form of the Star of David. Thus, the nature of this international collaboration is constructed as sadistic in that the US and UK allegedly facilitate Jewish-Israeli domination and oppression.

The "direction" of influence between Jews/ Israel and Western powers is ambiguous with cartoons suggesting different patterns of control and subservience. Gavimo's aforementioned cartoon depiction of the US flag suggests that there is a close relationship between the US and Israel. Conversely, like Babai's cartoon of the Jewish infant delivered to Palestine by the US and the UK, Marcio Leite from Brazil ${ }^{54}$ constructs the US as a puppetmaster that controls the strings of an Orthodox Jew with a beard and sidelocks who in turn controls the strings of an Israeli soldier. The Israeli soldier, consistent with the social representation of Israeli brutality, uses his strings to hang a Palestinian. Conversely, Khaldoon Gharaibeh from Jordan ${ }^{55}$ represents Jews as controlling the world - Gharaibeh depicts a grinning Jew wearing a black hat with the Star of David playing with a yo-yo in the form of the planet, suggesting Jewish world domination, a social representation that has existed since at least the 1800s (Herf, 2006). This image is similarly presented in the aforementioned cartoon by Gharaibeh which depicts the "l" of "Israel" as a boot crushing the earth. Taken together, the cartoons construct a representation of JewishZionist world domination. Crucially, the "Holocaust myth" is represented as an important means of deceiving the world into subservience to the Jewish-Zionist conspiracy (Lipstadt, 1994). This is depicted in a cartoon by Mohammad Aladwani from Iraq ${ }^{56}$ which represents the world as tearfully sympathizing with a Jew crying because of an apparently trivial wound on his finger but as willingly turning its back on a Palestinian with a severed hand. Similarly, in a cartoon by Mostafa Hosseini from Iran ${ }^{57}$ the world is indifferent to its severed arm (Palestine) and instead fixates tearfully on its plastered finger spelling the word "Holocaust." In short, there are different ways of objectifying Jewish and Palestinian suffering, which highlights the differential extent of gravity - the Jewish suffering is objectified in terms of a trivial finger wound, while Palestinian suffering in terms of a severed arm.

\section{DISCUSSION}

Although many of the cartoonists are not Iranian citizens, inclusion of their cartoons in a statesanctioned cartoon contest renders them a cohesive part of the Islamic Republic of Iran's political and ideological discourse on Israel, Jews and the Holocaust (Litvak, 2006; Shahvar, 2009). Moreover, the idiographic mode of analysis employed in this article elucidates the political and ideological idiosyncrasies of each cartoon(ist) and how they converge with antiSemitic motifs already present in the Iranian politico-ideological discourse in order to create particular social representations of Jews and Israel.

By endorsing the cartoon contest, the Islamic Republic of Iran sought to reiterate its longstanding commitment to anti-Zionism and to export and "internationalize" this ideology beyond its borders. This intention was undoubtedly facilitated by the fact that cartoonists from many non-Muslim countries participated (see figure 1), the international publicity that the contest received, and the widespread dissemination of the cartoons on the Internet (Bounegro \& Forceville, 2011). A core goal of the contest was also to normalize Holocaust denial as a tool for delegitimizing the State of Israel and challenging its raison d'être (Küntzel, 2012). This 
undoubtedly formed part of President Ahmadinejad's hardline government's policy of reversing the "liberal" reforms of the outgoing government of former president Mohamad Khatami.

Moreover, by denying the Holocaust and, thus, espousing a particularly provocative and defiant response to the Danish cartoon controversy, in which Islam was deemed to have been insulted by the West, the Islamic Republic attempted to reassert itself as the leading "defender" of Islam, as it had done in the aftermath of the Rushdie Affair in 1989 (Fischer, 2009). Iran's continued reputation of standing up to the West in this way surely bolstered the regime's sense of selfefficacy and distinctiveness, while the perpetuation of its anti-Zionist and anti-Semitic agenda safeguarded its sense of continuity (Jaspal, 2013a).

Despite the allegedly anti-Zionist intentions of the organizers, the cartoons overtly draw upon long-standing anti-Semitic themes and motifs, such as (i) ritual murder; (ii) the blood libel; and (iii) Jewish world domination and social representations of Jews as "demonic" and "bloodthirsty," which have been observed in previous research into cartoon depictions of Jews and Israel (Kotek, 2009; Smith, 2012; Stav, 1999). These themes and descriptions reflect "antisemyths" originally associated with European anti-Semitism but which have gradually come to form part of the Arab/Muslim discourse on Jews and Israel. Building upon this body of work, this article outlines how these themes converge with one another in the context of the cartoon contest and how the processes of anchoring and objectification function in order to produce negative social representations of Jews and Israel. More generally, the article demonstrates the unambiguously anti-Semitic character of the contest, which was represented by the organizers as being a celebration of "freedom of speech" and as a criticism of the State of Israel (Fischer, 2009). Given their systematic conflation of Judaism and Zionism, the cartoons depict the hybrid "Jew-Zionist" as the key protagonist who is evil and brutal; fabricates Holocaust knowledge; and conspires to dominate the world. Crucially, the central theme of Holocaust denial in the cartoons was surely intended to shock sensibilities and to provoke protest from the West, which would in turn provide the Iranian regime with an opportunity to represent the West as impeding "freedom of speech" and themselves as struggling to safeguard it (Küntzel, 2012). Moreover, Western protest to the Holocaust cartoon contest would enable the Iranian regime to point to "Zionist domination" of the West. In addition to using Holocaust denial as an instrument of anti-Zionism, this theme also served to construct negative (anti-Semitic) social representations of the JewZionist.

\section{Emerging social representations of the Jew-Zionist}

The cartoons construct a social representation that the "Evil Jew" and "Brutal Israel" (itself a proxy of the "Evil Jew," Bergman \& Heitmeyer, 2005) pose a universal threat. The threat allegedly targets Palestinians and Muslims in particular, but also the world more generally. The "core" of this representation conflates Jews and Israel and dehumanizes them as a devilish, bloodthirsty, parasitical and tyrannical collaborative force, which has a proclivity for committing atrocious acts against Gentiles (Yadlin, 1999). The cartoons elaborately construct the "Evil Jew" and "Brutal Israel" as inherently opposed to righteousness, benevolence and peace and, in accordance with their allegedly evil and brutal character, as embracing violence and brutality, particularly against the Palestinian people. The Palestinians are, conversely, represented as the weak, vulnerable and innocent victims of Jewish-Zionist aggression. The visual depiction of callous brutality of the Jews and the Israeli army constitutes an important element of the emerging threat representation, because it resonates with images of Israeli brutality against the Palestinians which are widely disseminated in the media (Litvak \& Webman, 2009). This facilitates the construction of the Palestinian Nakba, frequently alluded to in the cartoons, as having induced greater suffering than the Holocaust in which six million Jews were systematically murdered (Linn \& Gur-Ze'ev, 1996). In short, there is an implicit "competition" for victimhood status in the cartoons. Moreover, the threat representation is further reinforced 
through reference to the "Jewish world domination" motif, namely the notion that Jews hold disproportionate power in global affairs and mold UK and US policy to their liking. Cartoonists construct the world as being at the mercy of the powerful Jew-Zionist and as passively compliant with its malevolent intentions.

In accordance with the revisionist agenda of the cartoon organizers and of the Iranian regime more generally, the cartoons collectively construct the social representation that mainstream Holocaust knowledge is false. In some cartoons, there is a contestation of "Jewish control of the Holocaust" (Litvak \& Webman, 2009, p. 183). In their historical research into the evolution of Arab perceptions of the Holocaust, Litvak and Webman (2009) observe contradictory constructions of the Nazi Holocaust, some of which deny the Holocaust in its entirety and others which acknowledge it but nonetheless diminish its significance vis-à-vis current Palestinian suffering. The cartoons analyzed exhibit such variation. Yet, they all converge in depriving the Holocaust of any moral or political significance in order to delegitimize the State of Israel while simultaneously portraying the Jew-Zionist as a callous and evil manipulator. Accordingly, the cartoons "provide a lens through which an implied version of the past may be examined vis-à-vis present conditions" (Greenberg, 2002, p. 186). The "Western narrative" concerning the Nazi Holocaust, which the organizers overtly seek to undermine, is reinterpreted vis-à-vis the ongoing "Nakba" of the Palestinians. This performs a delegitimizing function (Litvak \& Webman, 2009).

Even those cartoons which acknowledge the reality of the Holocaust depict it as being maliciously exploited by the Jew-Zionist for evil and aggressive purposes, which is consistent with the threat representation. The "Western narrative" concerning the Holocaust is represented as facilitating brutality against the Palestinian people, as allowing the Jew-Zionist to realize his allegedly malicious intentions, and as "protecting" Zionism and Israel from external criticism. Several cartoons construct the Jew-Zionist as exploiting the world's sympathy for the plight of the Jews. In short, by satirizing the Holocaust in this way, the cartoons seek to express "criticism of the abuse of power and the injustice perpetrated by the dominant party [in this case, the JewZionist]" (Bal et al., 2009, p. 230).

There is an overarching social representation that Zionism is supported by an international conspiracy (Wistrich, 2004). This accentuates the threat representation, since the threat is depicted as being global and all-encompassing, and reiterates the representation that the Holocaust is a hoax. Cartoons depict a historical conspiracy, firstly, by aligning Zionism with Nazism and, secondly, by constructing a covert historical collaboration between Nazis and the Jew-Zionist (Litvak \& Webman, 2009). This is embodied in the visual "mixing" of Jewish, Zionist and Nazi symbols, particularly the Nazi swastika and the Star of David (Smith, 2012; Yadlin, 1999). Where the Holocaust is not overtly denied, there is a constructed transitivity between the anti-Semitic actions of the Nazis and the allegedly anti-Palestinian actions of the Jew-Zionist (Fischer, 2009). This diminishes the significance of the Holocaust, on the one hand, and accentuates the threat representation (of the Jew-Zionist), on the other. This visual representation resonates with the long-standing assertion of many Arab historians that there is ideological similarity between Nazism and Zionism and that there was a covert collaboration between Nazis and Zionists in the Final Solution (see Litvak \& Webman, 2009). Furthermore, several cartoons construct a contemporary international conspiracy consisting of Israel, the US and the UK, which allegedly provide mutual support and encouragement to one another. This resonates with the age-old anti-Semitic representation of "Jewish world domination" (Herf, 2006).

\section{Conclusions}

As a response to the Danish cartoon controversy, the International Holocaust Cartoon Contest served several important functions for the Islamic Republic of Iran - maintaining continuity of 
their politico-ideological agenda and bolstering self-efficacy and distinctiveness in the Muslim world, in particular. Although the organizers of the contest claimed that their aims were antiZionist and not anti-Semitic, this article elucidates the overtly anti-Semitic character of the contest and its cartoons. The cartoons themselves actively draw upon anti-Semitic imagery some more overtly than others - in delegitimizing Israel and Zionism. They feature a synthesis of "theological, moral, racial, social and political negation," which conflates Jews and Zionists (Stav, 1999, p. 18), and reproduce the dominant "anti-semyths" that have featured prominently in both European and Arab manifestations of anti-Semitism. Holocaust denial is a core theme in the cartoons, and serves the function of delegitimizing the State of Israel and demonizing Jews. Although anti-Zionism may well be the "goal" of some cartoonists, the imagery evoked in order to delegitimize Israel and Zionism is quite unambiguously anti-Semitic. More generally, scholars have convincingly argued that anti-Zionism in fact constitutes a form of anti-Semitism, because it reflects a prejudicial rejection of the Jewish right to national self-determination (Kotek, 2009; Webman, 2010).

It would not be an exaggeration to suggest that cartoons like the ones analyzed in this article accentuate growing global animosity towards Israeli Jews but also towards non-Israeli Jews who are increasingly held responsible for the actions of the Israeli government (Kotek, 2009). Anti-Semitism is on the rise and there is evidence that, in many cases, it is linked to negative social representations of Israel, which are freely disseminated by the international media and the cartoons analyzed in this article. These satirical cartoons provide their viewers with a distorted, one-sided version of the Israeli-Palestinian conflict and of Jewish history, and may therefore shape viewers' beliefs concerning Jews and Israel in fundamentally negative ways. The appeal to the Islamic Ummah through constructed Jewish-Zionist threats to Islam and Muslims could contribute to anti-Jewish feeling among Muslims in particular (Jiheli, 2009), while systematic Holocaust denial risks diminishing public understanding of the potential horrors of group prejudice and dehumanization (Haslam, 2006). By endorsing the International Holocaust Cartoon Contest, the Islamic Republic of Iran sought to "normalize" Holocaust denial (that is, anti-Semitism) as a legitimate means of criticizing Israel and Zionism, creating ideal conditions for negative intergroup relations and social disharmony.

\section{REFERENCES}

Bal, A.S., Pitt, L., Berthon, P. \& DesAtuels, P. (2009). Caricatures, cartoons, spoofs and satires: Political brands as butts. Journal of Public Affairs, 9, 229-237.

Bergman, W. \& Heitmeyer, W. (2005). Communicating anti-Semitism: Are the boundaries of the speakable shifting? In M. Zuckermann (Ed.), Antisemitismus - Antizionismus Israelkritik (Vol. XXXIII, pp. 70-89). Göttingen: Wallstein Verlag.

Bounegru, L. \& Forceville, C. (2011). Metaphors in editorial cartoons representing the global financial crisis. Visual Communication, 10, 209-225.

Braun, V. \& Clarke, V. (2006). Using thematic analysis in psychology. Qualitative

Research in Psychology, 3, 77-101.

Chesler, P. (2003). The New Anti-Semitism: The current crisis and what we must do about it. San Francisco, CA: Jossey-Bass.

Cohen, F., Jussim, L., Harber, K.D. \& Bhasin, G. (2009). Modern Anti-Semitism and AntiIsraeli Attitudes. Journal of Personality and Social Psychology, 97(2), 290-306.

Elliott, R., Fischer, C.T. \& Rennie, D.L. (1999). Evolving guidelines for publication of qualitative research studies in psychology and related fields. British Journal of Clinical Psychology, 38, 215-29.

Fischer, M.M.J. (2009). Iran and the Boomeranging Cartoon Wars: Can Public Spheres At

Risk Ally With Public Spheres Yet to be Achieved? Cultural Politics, 5(1), $27-62$.

Greenberg, J. (2002). Framing and Temporality in Political Cartoons: A Critical Analysis of 
Visual News Discourse. The Canadian Review of Sociology and Anthropology, 39(2), 18198.

Haslam, N. (2006). Dehumanization: An integrative review. Personality and Social Psychology Review, 10(3), 252-264.

Herf, J. (2006). The Jewish enemy: Nazi propaganda during World War II and the Holocaust. Cambridge, Mass., London: Bellknap Press of Harvard University Press. Hussain, A.J. (2009). The Media's Role in a Clash of Misconceptions: The Case of the Danish Muhammad Cartoons. The International Journal of Press/Politics, 18(2), 112-130. Jaspal, R. (2013a). Anti-Semitism and Anti-Zionism in Iran. Israel Affairs 19(2), 231-58.

Jaspal, R. (2013b). Israel in the Iranian Media: Demonizing the "Zionist Regime". Israel Journal of Foreign Affairs, 7(1), 77-86.

Jaspal, R. (in press). Representing the "Zionist Regime": Mass Communication of AntiZionism in the English-language Iranian Press. British Journal of Middle Eastern Studies. Jiheli, G. (2009). Antisemitism among young Muslims in London. Paper presented at the International Study Group Education and Research on Antisemitism Colloquium 1: Aspects of Antisemitism in the UK, 5 December 2009. http://www.iibsa.org/cms/fileadmin/downloads/london_symposia/Gunther_Jikeli.pdf Klüsener, E. (2008). Jews in Iran since the revolution of 1979: Caught between a rock and a hard place. Norderstadt: GRIN Verlag.

Kotek, J. (2009). Cartoons and extremism: Israel and the Jews in Arab and Western media. Edgware: Vallentine Mitchell.

Küntzel, M. (2010). Iranian anti-Semitism: stepchild of German National Socialism. Israel Journal of Foreign Affairs, 4(1) 43-51.

Küntzel, M. (2012). Iranian holocaust denial and the Internet. Israel Journal of Foreign Affairs, 6(1), 43-52.

Lindemann, A.S. \& Levy, R.S. (2010). Antisemitism: A history. Oxford: Oxford University Press.

Linder, S.H. (2006). Cashing-In on Risk Claims: On the For-Profit Inversion of Signifiers for "Global Warming". Social Semiotics 16(1), 103-32.

Linn, R. \& Gur-Ze'ev, I. (1996). Holocaust as metaphor: Arab and Israeli use of the same symbol. Metaphor and Symbolic Activity, 11(3), 195-206

Lipstadt, Deborah E. (1993). Denying the Holocaust: The growing assault on truth and memory. New York: Plume.

Litvak, M. (2006). The Islamic Republic of Iran and the Holocaust: Anti-Semitism and Anti-Zionism. Journal of Israeli History, 25(1), 267-84

Litvak, M. \& Webman, E. (2009). From empathy to denial: Arab responses to the

Holocaust. New York: Columbia University Press.

Menashri, D. (2006) Iran, Israel and the Middle East conflict. Israel Affairs, 12(1), 107-22.

Moloney, G., Holtz, P. \& Wagner, W. (2013). Editorial political cartoons in Australia:

Social representations and the visual depiction of essentialism. Integrative Psychological and Behavioral Science, 47(2), 284-98.

Moscovici, S. (1988). Notes towards a description of social representations. European Journal of Social Psychology, 18, 211-250.

Nerlich, N. \& Jaspal, R. (in press). Images of Extreme Weather: Symbolising Human Responses to Climate Change. Science as Culture.

Palmer-Harik, J. (2004). Hezbollah: The Changing Face of Terrorism. London, I.B. Tauris \& Co Ltd

Shahvar, S. (2009). The Islamic Regime in Iran and Its Attitude towards the Jews: The Religious and Political Dimensions. Immigrants \& Minorities, 27(1), 82-117. 
Sivan, E. (1995). Mythes politiques arabes. Paris: Fayard.

Smith, S.W. (2012). Cartoons and the new anti-Semitism. Unpublished M.Sc. dissertation, Massey University, Wellington, New Zealand.

Stav, Arieh. (1999). Peace: The Arabian caricature: A study of anti-Semitic imagery. New York: Gefen Publishing House, Ltd.

Taguieff, P. (2004). Rising from the muck: The new anti-Semitism in Europe. Chicago: Ivan R. Dee.

Yadlin, R. (1999). Anti-Jewish imagery in the contemporary Arab-Muslim world. In R.S. Wistrich (Ed.), Demonizing the Other: Antisemitism, racism and zenophobia (pp.309-321).

Amsterdam: Harwood Academic Publishers.=

Webman, E. (2010). The challenge of assessing Arab/Islamic antisemitism. Middle Eastern Studies, 46(5), 677-97.

Wistrich (Ed.) (1999) Demonizing the Other: Anti-semitism, Racism and Xenophobia.

Amsterdam: Harwood Academic Publishers.

Wistrich, R.S. (2004). Antizionism and anti-Semitism. Jewish Political Studies Review

16(3-4). http://jcpa.org/phas/phas-wistrich-f04.htm

Wistrich, R.S. (2005). European anti-Semitism reinvents itself. New York: The American Jewish Committee.

\footnotetext{
${ }^{1} \mathrm{http}: / / \mathrm{www}$. irancartoon.ir/gallery/album48

${ }^{2} \mathrm{http}: / / \mathrm{www}$. irancartoon.ir/gallery/album48/Abdolhossein Amirizadeh Ira

${ }^{3} \mathrm{http}: / / \mathrm{www}$. irancartoon.ir/gallery/album48/Majid_Salehi_Iran2

${ }^{4} \mathrm{http} / / / \mathrm{www}$. irancartoon.ir/gallery/album48/Sadic_Pala_India_3

${ }^{5} \mathrm{http} / / / \mathrm{www}$. irancartoon.ir/gallery/album48/Sadic_Pala_India_2

${ }^{6} \mathrm{http} / / / \mathrm{www}$. irancartoon.ir/gallery/album48/Alaa_Rostam_Syria

${ }^{7} \mathrm{http} / / / \mathrm{www}$. irancartoon.ir/gallery/album48/Sam_Keshmiri_Iran

${ }^{8} \mathrm{http}: / / w w w . i r a n c a r t o o n . i r / g a l l e r y / a l b u m 48 /$ Majid_Salehi_Iran

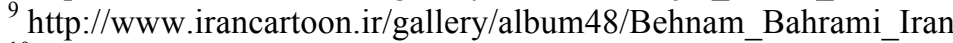

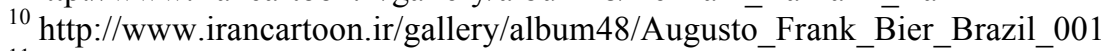

${ }^{11} \mathrm{http}: / /$ www.irancartoon.ir/gallery/album48/CarlosLatuffBrazil

${ }^{12} \mathrm{http} / / / \mathrm{www}$. irancartoon.ir/gallery/album48/CarlosLatuffBrazil2

${ }^{13} \mathrm{http}: / / \mathrm{www}$. irancartoon.ir/gallery/album48/Iran3

${ }^{14} \mathrm{http}: / /$ www.irancartoon.ir/gallery/album48/Miroslaw_HAJNOS_Poland

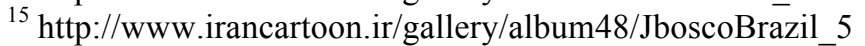

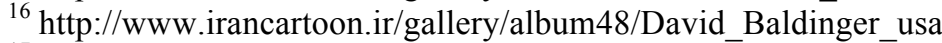

${ }^{17} \mathrm{http}: / /$ www.irancartoon.ir/gallery/album48/Ebrahim_Azad_Iran

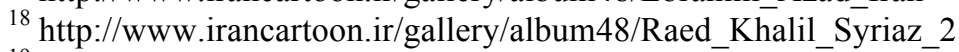

${ }^{19} \mathrm{http}: / /$ www.irancartoon.ir/gallery/album48/Djoko_Susilo_2

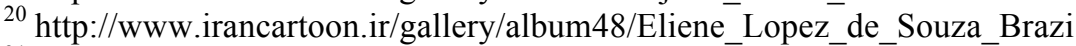

${ }^{21} \mathrm{http}: / /$ www.irancartoon.ir/gallery/album48/Raed_Khalil_Syriaz_3

${ }^{22} \mathrm{http}: / / w w w . i r a n c a r t o o n . i r / g a l l e r y / a l b u m 48 /$ khaldoon_gharaibehjordan

${ }^{23} \mathrm{http}: / / w w w . i r a n c a r t o o n . i r / g a l l e r y / a l b u m 48 / N e d a l \_A \overline{l i}$ Deep_syria_1

${ }^{24} \mathrm{http}$ ///www.irancartoon.ir/gallery/album48/Homayoun_Abdolrahimi

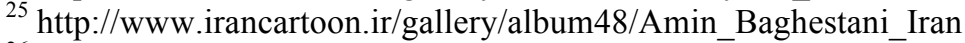

${ }^{26} \mathrm{http}: / /$ www.irancartoon.ir/gallery/album48/Rahim_Taghipour_Sedgh_Razmj

${ }^{27} \mathrm{http}: / /$ www.irancartoon.ir/gallery/album48/tALLIL_aBDELLATIF_1

${ }^{28} \mathrm{http}: / / \mathrm{www}$. irancartoon.ir/gallery/album48/Hossein_Taheri_Iran

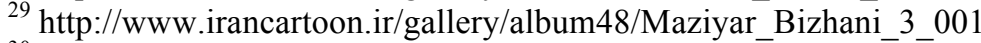

${ }^{30} \mathrm{http}: / /$ www.irancartoon.ir/gallery/album48/Jihad_AwrtaniJordan_1

${ }^{31} \mathrm{http}: / / w w w . i r a n c a r t o o n . i r / g a l l e r y / a l b u m 48 / J i h a d$ AwrtaniJordan

${ }^{32} \mathrm{http}: / /$ www.irancartoon.ir/gallery/album48/Sadic Pala India 1

${ }^{33} \mathrm{http}: / / \mathrm{www}$. irancartoon.ir/gallery/album48/Jaber_Asadi Iran

${ }^{34} \mathrm{http}: / /$ www.irancartoon.ir/gallery/album48/Jaber_Asadi_Iran_3

${ }^{35} \mathrm{http}: / /$ www.irancartoon.ir/gallery/album48/Tommy_Thomdean_Indonesia_5

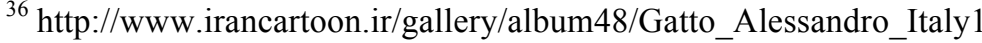


${ }^{37} \mathrm{http}: / /$ www.irancartoon.ir/gallery/album48/carlos_Latuff_Brazil

${ }^{38} \mathrm{http}: / /$ www.irancartoon.ir/gallery/album48/Abdellah_Derkaoi_Morocco1

${ }^{39} \mathrm{http}: / / \mathrm{www}$.irancartoon.ir/gallery/album48/shiva_sahamifard_iran

${ }^{40} \mathrm{http}: / / \mathrm{www}$. irancartoon.ir/gallery/album48/Sidnei_Marques_Brazil

${ }^{41} \mathrm{http}: / / \mathrm{www}$. irancartoon.ir/gallery/album48/Galym

${ }^{42} \mathrm{http}: / / \mathrm{www}$. irancartoon.ir/gallery/album48/soheil_setayesh_1

${ }^{43} \mathrm{http}: / / \mathrm{www}$.irancartoon.ir/gallery/album48/Choukri_BellahadiAlgeria_1

${ }^{44} \mathrm{http}: / / \mathrm{www}$. irancartoon.ir/gallery/album48/Mohammad_Aman_Bahrain

${ }^{45} \mathrm{http}: / / \mathrm{www}$.irancartoon.ir/gallery/album48/Alireza_Nosrati_Iran

${ }^{46} \mathrm{http}: / /$ www.irancartoon.ir/gallery/album48/Maziyar_Bizhani_11_001

${ }^{47} \mathrm{http}: / / \mathrm{www}$.irancartoon.ir/gallery/album48/Mohammad_Aman_Bahrain

${ }^{48} \mathrm{http}: / / \mathrm{www}$. irancartoon.ir/gallery/album48/Leo_Garesia_USA

${ }^{49} \mathrm{http}: / / \mathrm{www}$. irancartoon.ir/gallery/album48/Yasin_Alkhalils

${ }^{50} \mathrm{http}: / / \mathrm{www}$. irancartoon.ir/gallery/album48/Jitet_Koestana_Indonesia_3

${ }^{51} \mathrm{http}: / / \mathrm{www}$. irancartoon.ir/gallery/album48/Gavimo_Brazil

${ }_{52}^{52} \mathrm{http}: / /$ www.irancartoon.ir/gallery/album48/Esmail_Babai_Iran

${ }_{53}^{53} \mathrm{http}: / /$ www.irancartoon.ir/gallery/album48/Naji_Benji_Morocco

${ }_{55}^{54} \mathrm{http}: / /$ www.irancartoon.ir/gallery/album48/Marcio_Leite_Brazil

${ }_{55}^{5} \mathrm{http}: / / \mathrm{www}$. irancartoon.ir/gallery/album48/khaldoon_gharaibehjordan_1

${ }^{56} \mathrm{http} / / / \mathrm{www}$.irancartoon.ir/gallery/album48/mohammed_aladwani_iraq

${ }^{57} \mathrm{http}: / /$ www.irancartoon.ir/gallery/album48/Mosatafa_Hosseini_Iran 